\title{
Seniorpreneur as a career option for smart active ageing. A study on Romania
}

\author{
Carmen PĂUNESCU \\ The Bucharest University of Economic Studies, Bucharest, Romania \\ carmen.paunescu@ase.ro \\ Laura BLID \\ The Bucharest University of Economic Studies, Bucharest, Romania
}

\begin{abstract}
The ageing of population is a global phenomenon and solutions are looked for in order to milder the economic impact. One alternative is supporting active ageing through development of entrepreneurship among senior population. Seniors are a valuable resource for entrepreneurship. They often have the skills, financial resources and time available to contribute to economic activity. This will lead to the growing prevalence of senior entrepreneurship. Engaging seniors in both business creation and in supporting new and existing entrepreneurs would maximize the quality of their working life, nurture intergenerational learning and ensure knowledge transfer. In this respect, the paper seeks to answer the following questions: What is the seniors' perception about entrepreneurship and self-employment in Romania? How desirable is a self-employed career for senior population? What are the motivations of Romanian senior population to become self-employed? To achieve these objectives, the paper analyzes the pulse of self-employment in Romania for people from the age group 60+ years. The data used are extracted from the Amway Global Entrepreneurship Reports (AGER) developed for Romania, for the period 2014-2016. Analysis is conducted by taken into considerations the following dimensions of the "entrepreneurship perception": attitude towards entrepreneurship, intention of starting a business, entrepreneurship career appealing and entrepreneurship motivations. The findings of the paper show that, in general, people over 60 years exhibit a decreasing positive perception about entrepreneurship that can be explained by multiple reasons. In the paper we raise some key issues that require consideration by policy makers in order to support senior entrepreneurship in Romania and improve seniors' quality of life.
\end{abstract}

Keywords: senior entrepreneurship, active ageing, Romania, Amway Global Entrepreneurship Report, entrepreneurship perception.

\section{Introduction}

According to World Bank statistics, in 2015, Romania ranks on 45th position in terms of ease of doing business and on 37th position in starting a business, out of 189 economies (International Bank for Reconstruction and Development/ The World Bank, 2016a). This shows an improvement relative to last years, when Romania ranked 48 in 2014 and 73 in 2013. Doing business report 2016 assesses the economic environment in Romania, in terms of starting a business, as being comparable to 2010, Romania ranking 45, so worsening in comparison to 2015, but still above regional average in Europe and Central Asia (International Bank for Reconstruction and Development/ The World Bank, 2016b). 
The competitiveness ranking for 2015-2016 from World Economic Forum (2015) presents Romania on place 53 from 140 states, mentioning among others very low levels of the "country capacity to retain talents" (ranking 131 out of 140 countries), "venture capital availability" (ranking 103 out of 140), "effect of taxation on incentives to invest" (ranking 126), and for "institutions and infrastructure" (ranking 86). With regard to "innovation and business sophistication", the report indicates modest potential for Romania with scores below the EU average, for both ranking only 75 in innovation, and 88 in terms of business sophistication. At the chapter "company spending on R\&D", Romania ranks 94 and at "government procurement of advanced technology products" it ranks 105. These all are reflecting the nature of business environment and are impacting the entrepreneurship development.

Promoting senior entrepreneurship was one of the goals of 2012 European Year of Active Ageing and Solidarity between Generations (OECD/European Union, 2012). Seniors are recognized as a valuable resource for entrepreneurship. Engaging senior population in both business creation and in supporting new and existing entrepreneurs would maximize both the quality of their working life and their wealth experience, as well as will nurture intergenerational learning and ensure knowledge transfer (Kurek and Rachwal, 2011; OECD/European Union, 2012; Ruis and Scholman, 2012). European Union is highly supporting the idea of senior entrepreneurship and is looking for solutions to stimulate this. Romania has to align to the European Union policies. The evolution of entrepreneurship among persons aged 55-64 (considering total early-stage entrepreneurship) in Romania was showing a decrease in 2009 most probably mainly due to the financial crisis and a positive evolution in 2011 and 2014 compared to the previous year. Romania is offering a good business environment for starting a business, however is facing also some difficulties and is far from offering a good support for this particular age category to develop entrepreneurial activities.

The present paper attempts to analyze the pulse of self-employment in Romania for people from the age group 60+ years. To this purpose, it explores entrepreneurship perception relating to senior population in Romania. Also, the paper raises some key issues for policy makers to be considered in designing policy interventions meant to enhance senior entrepreneurship in Romania and improve their life quality.

\section{Literature review}

\section{Characteristics of senior entrepreneurship}

There is relatively little critical work about the role of (all) age(s) in an organizational context and, therefore, a wide opportunity to contribute much more directly to debates around age (Thomas et al., 2014). According to Fachinger and Bögenhold (2016) older entrepreneurship is defined as the discovery, evaluation and exploitation of future goods and services when in age 50 and above. Previous literature on senior entrepreneurship (e.g., Singh and DeNoble, 2003; Kautonen, Down and Minniti, 2014; Kautonen et al., 2015) brings out that there would be a combination of social, financial and personal reasons for early retirees' decision to become self-employed. Also, selfemployment is primarily taken by retirees with relatively high levels of financial and 
human capital, those possessing entrepreneurial positive attitudes and those who perceive their retirements to be completely involuntary (Van Solinge, 2014).

Age is one of the most important determinants of entrepreneurship and selfemployment (Parker, 2009). Scholars found that the effect of age on the probability of engaging in entrepreneurship follows an inverse U-shape (Lévesque and Minniti, 2006; Bergmann and Sternberg, 2007; Parker, 2009). Although, willingness to start a business decreases with age, while the opportunity to do so increases (Blanchflower and Oswald, 2004). The older people are significantly less likely to engage in entrepreneurial activities compared to younger individuals (Curran and Blackburn, 2001). Lévesque and Minniti (2006) explained the declining willingness to start a business with the age based on opportunity cost of time, which increases with age and discourages older individuals from selective forms of employment that involve risk. Plus, some scholars talk about the strong negative relation between age and the innovation strategy, investment and turnover (Ruis and Scholman, 2012).

By examining older retired workers' engagement in post-career entrepreneurship and wage-and-salary employment, Kerr and Armstrong-Stassen (2011) found that those choosing entrepreneurship exhibited different demographic characteristics and psycho-social needs that those choosing employment. Singh and DeNoble (2003) argue that older population have a higher probability to become entrepreneur as they may possess more human capital than younger ones due to lifelong learning and on-the-job-training. Also, older entrepreneurs seem to start businesses with a higher survival rate than younger founders (Verheul and van Stel, 2007).

A study on North of England shows that there is a growing interest in selfemployment among people aged 50 and over. Men were more likely to seek continuing employment, while women were more enthusiastic about self-employment and business creation (Lamotte and Colovic, 2013). Kean et al. (1993) identified five major themes associated with successful aging of older entrepreneurs that emerged for women, namely autonomy, independence, self-reliance, personal effectiveness, and intergenerational support. However, there are many factors which might discourage seniors from entrepreneurial activity, like technological developments, high administrative and tax burden (Pilkova et al., 2014). Although, contrary to classic stereotyping, senior entrepreneurs remain highly ambitious and open to technological developments (Harms et al., 2014).

Kautonen et al. (2011) shows that work history becomes a significant determinant of entrepreneurial intentions only at people later career stages. In an empirical study of Finnish individuals, Kautonen et al. (2011) found that social norms perceived as permissive of enterprising activity in the third age, i.e. in the age 50 and above, exert a significant positive influence of entrepreneurial intentions in this age segment.

Education appears to have a positive effect on opportunity, necessity, social entrepreneurship and on growth ambitions. Verheul and van Stel (2007) found that in less developed countries older and higher educated entrepreneurs are particularly important for stimulating economic growth, while for highly developed countries the contribution of younger entrepreneurs is more important. 
The ageing population can negatively affect employment creation, as older entrepreneurs are less likely to become employers (Kok et al., 2010). Usually, entrepreneurship is associated with youth, yet those over 50 more frequently start new businesses, and appear to be more successful at surviving the critical first three years of operation than their younger counterparts. However, these new businesses often take the form of self-employment as a way out of unemployment, rather than growth-oriented enterprises that can provide jobs for others (Ainsworth, 2015).

Entrepreneurship is key in solving socio-economic issues of ageing population and a key priority of the EU regional policy (Kurek and Rachwal, 2011). Differences among countries' level of senior entrepreneurship are mainly driven by national entrepreneurial environment, in government policies, meaning both concrete policies aimed at the support of entrepreneurship as well as the bureaucracy and taxes framework (Pilkova et al., 2014). Entrepreneurs develop stronger growth aspirations in countries with a stronger rule of law. A number of support systems have been established for youth start-ups, but there are few government support policies in place for senior start-up market.

\section{Methodology}

The paper attempts to explore the perception about self-employment and entrepreneurship motivations of population from age group 60+ years from Romania. To achieve this main goal, the paper has three specific objectives: (1) to analyze attitudes towards entrepreneurship and self-employment for senior population; (2) to analyze the desirability of population from age group 60+ years to consider selfemployment as a career choice; and (3) to understand the motivations of senior population to create their own business.

For this purpose, the current research analyzes the data available from the Amway Global Entrepreneurship Reports (AGER) developed for Romania, for the period 2014-2016. The total number of valid questionnaires interpreted in the reports was 1,052 in 2014, 1,084 in 2015 and 1,023 questionnaires in 2016. The market population used in the AGER survey, selected from the whole population universe of Romania, ensured a representative sample. The data selected for the current analysis refers to senior population from the age group 60+ years, for Romania (2014: $n=254$, 2015: $n=288$ and 2016: $n=271$ ).

In the paper we analyze the entrepreneurship perception of senior population by taking into consideration the following dimensions: attitude towards entrepreneurship, intention of starting a business, entrepreneurship career appealing, and entrepreneurship motivations.

\section{Results and discussion}

\section{Analysis of seniors' attitude towards entrepreneurship}

Our research findings for the studied population show that the positive attitude towards entrepreneurship is visibly decreasing from $54.1 \%$ in 2014 to $38.0 \%$ in 2016, with a decreasing rate of $29.7 \%$ (Table 1). The respondents base slowly increased from $2014(n=254)$ to $2016(n=271)$. Consequently, their negative attitude is 
increasing from $32.2 \%$ in 2014 to $43.5 \%$ in 2016 , with an even faster increasing rate of $35.1 \%$.

Table 1. Entrepreneurship attitude among age group 60+ in Romania.

\begin{tabular}{lccc}
\hline Entrepreneurship attitude & $\mathbf{2 0 1 4}$ & $\mathbf{2 0 1 5}$ & $\mathbf{2 0 1 6}$ \\
\hline Respondents base (100\%) & $\mathbf{2 5 4}$ & $\mathbf{2 8 8}$ & $\mathbf{2 7 1}$ \\
\hline $\begin{array}{l}\text { My attitude towards } \\
\text { entrepreneurship is positive }\end{array}$ & $54.1 \%(\mathrm{n}=137)$ & $39.3 \%(\mathrm{n}=113)$ & $38.0 \%(\mathrm{n}=103)$ \\
\hline $\begin{array}{l}\text { My attitude towards } \\
\text { entrepreneurship is negative }\end{array}$ & $32.2 \%(\mathrm{n}=82)$ & $38.7 \%(\mathrm{n}=111)$ & $43.5 \%(\mathrm{n}=118)$ \\
\hline \multicolumn{1}{c}{ Source: Processed based on Self-Employment / AGER 2014, 2015, 2016 - Romania }
\end{tabular}

\section{Analysis of seniors' intention to start a business and attractiveness of an entrepreneurship career}

Tornikoski and Kautonen (2009) found that the entrepreneurial intentions of older individuals are mostly influenced by their perception as to how easy or difficult they think starting up a business would be. This is also true for our findings, as a smaller and smaller number of people of age $60+$, who have a positive attitude towards entrepreneurship, can imagine starting their own business, representing a decrease of $72.6 \%$, from $8.4 \%$ in 2014 to $2.3 \%$ in 2016 (Table 2). However, in 2016 there are $2.0 \%$ of seniors with negative attitude towards entrepreneurship willing to become self-employed, but the trend line is decreasing as well relative to 2014 (3.1\%).

Table 2. Intention to start a business and entrepreneurship career appealing among age group $60+$ in Romania.

\begin{tabular}{lccc}
\hline \multicolumn{1}{c}{$\begin{array}{c}\text { Entrepreneurship } \\
\text { intention }\end{array}$} & $\mathbf{2 0 1 4}$ & $\mathbf{2 0 1 5}$ & $\mathbf{2 0 1 6}$ \\
\hline Respondents base (100\%) & $\mathbf{2 5 4}$ & $\mathbf{2 8 8}$ & $\mathbf{2 7 1}$ \\
\hline $\begin{array}{l}\text { My attitude towards } \\
\text { entrepreneurship is positive } \\
\begin{array}{l}\text { and I can imagine starting my } \\
\text { our business }\end{array}\end{array}$ & $8.4 \%(\mathrm{n}=21)$ & $7.0 \%(\mathrm{n}=20)$ & $2.3 \%(\mathrm{n}=6)$ \\
\hline $\begin{array}{l}\text { My attitude towards } \\
\text { entrepreneurship is negative } \\
\text { but however I can imagine } \\
\text { starting my our business }\end{array}$ & $3.1 \%(\mathrm{n}=8)$ & $1.0 \%(\mathrm{n}=3)$ & $2.0 \%(\mathrm{n}=5)$ \\
\hline $\begin{array}{l}\text { I consider starting a business } \\
\text { as a desirable career } \\
\text { opportunity for myself }\end{array}$ & N/A & & \\
\hline
\end{tabular}

Source: Processed based on Self-Employment / AGER 2014, 2015, 2016 - Romania.

Seniors' desirability to consider entrepreneurship as a career option is also low and decreasing in $2016(10.2 \%, \mathrm{n}=28)$ relative to $2015(19.1 \%, \mathrm{n}=55)$. This can be explained by the fact that only a small part of this population perceive the Romanian society as being entrepreneurship friendly. However, in 2016 more than one third of our studied population perceived that people in Romania, in five-years, will be more likely, or as likely as today, to be self-employed in full-time or part-time. 


\section{Analysis of seniors' motivations for entrepreneurship}

Our research findings show that while in 2014 getting second income prospects was the key driver for entrepreneurship among senior population (52.4\%), the situation changed in 2015 (34.9\%) and 2016 (33.4\%), this going on the second place (Table 3). Other reasons tend to be more important than those included in the survey and this requires additional investigations. Next it follows independence from an employer and desire of being own boss, with a slowly decreasing trend line from 2014 (29.6\%) to $2016(26.8 \%)$. On the next place as entrepreneurship drivers for seniors it is coming self-fulfillment and possibility to realize own ideas. However, only $11.9 \%$ $(n=32)$ of respondents mention this in 2016 relative to $21.1 \%(n=54)$ in 2014 . It is worth to mention that more people are motivated by possibility to return to job market in $2016(9.7 \%, \mathrm{n}=26)$ than previous year $(5.8 \%, \mathrm{n}=17)$.

Table 3. Reasons to start a business for senior population (60+ years) in Romania.

\begin{tabular}{lccc}
\hline Reasons to start a business & $\mathbf{2 0 1 4}$ & $\mathbf{2 0 1 5}$ & $\mathbf{2 0 1 6}$ \\
\hline Respondents base (100\%) & $\mathbf{2 5 4}$ & $\mathbf{2 8 8}$ & $\mathbf{2 7 1}$ \\
\hline $\begin{array}{l}\text { Better compatibility of } \\
\text { family, leisure time and } \\
\text { career }\end{array}$ & $16.2 \%(\mathrm{n}=41)$ & $7.4 \%(\mathrm{n}=21)$ & $6.8 \%(\mathrm{n}=19)$ \\
\hline Second income prospects & $52.4 \%(\mathrm{n}=133)$ & $34.9 \%(\mathrm{n}=100)$ & $33.4 \%(\mathrm{n}=91)$ \\
\hline $\begin{array}{l}\text { Self-fulfillment, possibility to } \\
\text { realize own ideas }\end{array}$ & $21.1 \%(\mathrm{n}=54)$ & $14.1 \%(\mathrm{n}=41)$ & $11.9 \%(\mathrm{n}=32)$ \\
\hline $\begin{array}{l}\text { Independence from an } \\
\text { employer, being my own } \\
\text { boss }\end{array}$ & $29.6 \%(\mathrm{n}=75)$ & $25.6 \%(\mathrm{n}=74)$ & $26.8 \%(\mathrm{n}=73)$ \\
\hline $\begin{array}{l}\text { Return to job market, } \\
\text { alternative to unemployment }\end{array}$ & $11.5 \%(\mathrm{n}=29)$ & $5.8 \%(\mathrm{n}=17)$ & \\
\hline \multicolumn{1}{l}{ Others } & $23.0 \%(\mathrm{n}=58)$ & $43.3 \%(\mathrm{n}=125)$ & $41.4 \%(\mathrm{n}=112)$ \\
\hline
\end{tabular}

\section{Conclusion}

The ageing of population is a global phenomenon and solutions are looked for in order to milder the economic impact. The development of entrepreneurship among ageing population is one alternative.

The existing literature on senior entrepreneurship is young, rapidly developing, while the topic remains new, actual, of interest and global importance. There are specific studies on ageing entrepreneurship, but still small in number. Many studies are mostly local and express limited conclusions, being small pieces of a big puzzle. There is still plenty of space for research. For Romania there are couple of a few publications and the topic is underexplored. In the literature, there is no clear consensus with regard to definition of main concepts or with regard to the factors influencing the willingness of older people to become entrepreneurs. Even the clear cut between self-employed and entrepreneurs is not precise. However the approaches are various and gained in diversity.

The paper reveals interesting insights in what regards perception about selfemployment of senior population in Romania. Our studied population mainly display 
a negative attitude towards entrepreneurship, and the trend line is increasing. The overall interest of population from age group 60+ years regarding intention of starting a business is declining. There are various drivers which might increase the willingness and desirability of senior population to become self-employed, and these require further investigation.

Therefore, solutions are looked for from policy-makers to address this issue, particularly since the general perception is that people in Romania will be more likely to be self-employed in five years from now.

\section{References}

Ainsworth, S. (2015). Ageing entrepreneurs and volunteers. Transition in late career. In: Bal, P. Matthijs, Kooij, Dorien T.A.M., Rousseau, Denise M. (Eds.), Aging Workers and the Employee-Employer Relationship, Springer International, 243-260.

Bergmann, H., Sternberg, R. (2007). The changing face of entrepreneurship in Germany. Small Business Economics, 28(2), 205-221.

Blanchflower, D.G., Oswald, A.J. (2004). Well-being over time in Britain and the USA, Journal of Public Economics, 88(7-8), 1359-1386.

Curran, J., Blackburn, R. (2001). Older people and the enterprise society: Age and selfemployment propensities, Work, Employment and Society, 15(4), 889-902.

European Commission (2015). The 2015 Ageing Report: Economic and budgetary projections for the 28 EU Member States (2013-2060), European Economy, 3, Retrieved from http://ec.europa.eu/economy_finance/publications/european_ economy/2015/pdf/ee3_en.pdf.

Fachinger, U., Bögenhold, D. (2016). Self-employment of older people: New chances and challenges for research. Discussion Paper, 26, Institut für Gerontologie Ökonomie und Demographischer Wandel, Universität Vechta.

Harms, R., Luck, F., Kraus, S., Walsh, S. (2014). On the motivational drivers of gray entrepreneurship: An exploratory study. Technological Forecasting and Social Change, 89, 358-365.

International Bank for Reconstruction and Development/ The World Bank (2016). Global economic prospects. Divergences and risks, June 2016, U.S.: Washington, D.C.

International Bank for Reconstruction and Development/ The World Bank (2016b). Doing business 2016. Measuring regulatory quality and efficiency, $13^{\text {th }}$ Edition, U.S.: Washington, D.C.

Kautonen, T., Tornikoski, E., Kibler, E. (2011). Entrepreneurial intentions in the third age: the impact of perceived age norms. Small Business Economics, 37(2), 219234.

Kautonen, T., Down, S., Minniti, M. (2014). Ageing and entrepreneurial preferences. Small Business Economics, 42(3), 579-594.

Kautonen, T., Hatak I., Kibler E., Wainwright, T. (2015). Emergence of entrepreneurship behavior. The role of age-based self-image, Journal of Economic Psychology, 50, 41-51.

Kean, R. C., Van Zandt, S., Maupin, W. (1993). Successful aging: The older entrepreneur, Journal of Women and Aging, 5(1), 25-42. 
Kerr, G., Armstrong-Stassen, M. (2011). The bridge to retirement: Older workers' engagement in post-career entrepreneurship and wage-and-salary Employment, The Journal of Entrepreneurship, 20(1), 55-76.

Kok, J. de, Ichou A., Verheul, I. (2010), New Firm Performance: Does the Age of Founders Affect Employment Creation?Retrieved from https://core.ac.uk/download/pdf/ 6445736.pdf .

Kurek, S., Rachwal, T. (2011). Development of entrepreneurship in ageing population of the European Union, Procedia - Social and Behavioral Sciences, 19, 397-405.

Lamotte, O., Colovic, A. (2013). Do demographics influence aggregate entrepreneurship? Applied Economics Letters, 20(3), 1206-1210.

Lévesque, M., Minniti, M. (2006). The effect of aging on entrepreneurial behavior, Journal of Business Venturing, 21(2), 177-194.

Lévesque, M., Minniti, M. (2011). Age matters: How demographics influence aggregate entrepreneurship, Strategic Entrepreneurship Journal, 5(3), 269-284.

OECD/European Union (2012). Policy Brief on the Senior Entrepreneurship, Entrepreneurial Activities in Europe, European Commission. Retrieved from https://www.oecd.org/cfe/leed/EUEMP12A1201_Brochure_Entrepreneurial_ Activities_EN_v7.0_accessible.pdf.

Parker, S.C. (2009). The economics of self-employment and entrepreneurship, Cambridge University Press, Cambridge, 113-160.

Pilkovaa, A., Holienkaa, M., Rehaka, J. (2014). Senior entrepreneurship in the perspective of European entrepreneurial environment, Procedia Economics and Finance, 12, 523-532.

Ruis, A., Scholman, G. (2012). Ageing and entrepreneurship. Scales Research Reports H201206, EIM Business and Policy Research. Retrieved from https://www.imk.nl/uploads/wp-content/helpdesk-wpcontent/uploads/2012/07/EIM-Ageing-and-entrepreneurship-H201206.pdf .

Singh, G., De Noble, A. (2003). Early retirees as the next generation of entrepreneurs, Entrepreneurship Theory and Practice, 23(3), 207-226.

Thomas, R., Hardy, C., Cutcher, L., Ainsworth, S. (2014). What's age got to do with it? On the critical analysis of age and organizations, Organization Studies, 35(11), 1569-1584.

Van Solinge, H. (2014). Who opts for self-employment after retirement? A longitudinal study in Netherland. European Journal of Ageing, 11(3), 261-272.

van Stel, A., Verheul, I. (2007). Entrepreneurial diversity and economic growth, Scales Research Reports H200701, EIM Business and Policy Research. Retrieved from http://www.entrepreneurship-sme.eu/pdf-ez/H200701.pdf.

World Economic Forum (2015). The global competitiveness report 2015-2016. Schwab, K. (Editor). Switzerland: Geneva. 